Columbia Law School

Scholarship Archive

2013

\title{
Regulatory Capabilities: A Normative Framework for Assessing the Distributional Effects of Regulation
}

\author{
Katharina Pistor \\ Columbia Law School, kpisto@law.columbia.edu \\ Fabrizio Cafaggi
}

Follow this and additional works at: https://scholarship.law.columbia.edu/faculty_scholarship

Part of the Public Law and Legal Theory Commons

\section{Recommended Citation}

Katharina Pistor \& Fabrizio Cafaggi, Regulatory Capabilities: A Normative Framework for Assessing the Distributional Effects of Regulation, Columbia LaW School Public LaW \& Legal TheORY Working PaPer No. 13-354 (2013).

Available at: https://scholarship.law.columbia.edu/faculty_scholarship/2281

This Working Paper is brought to you for free and open access by the Faculty Publications at Scholarship Archive. It has been accepted for inclusion in Faculty Scholarship by an authorized administrator of Scholarship Archive. For more information, please contact scholarshiparchive@law.columbia.edu. 


\section{Columbia Law School}

Public Law \& Legal Theory Working Paper Group

Paper Number 13-354

Regulatory Capabilities

A Normative Framework for Assessing the Distributional Effects of Regulation

Fabrizio Cafaggi

European University Institute

Katharina Pistor

Columbia Law School

July 5, 2013 


\title{
Regulatory Capabilities ${ }^{1}$
}

\section{A Normative Framework for Assessing the Distributional Effects of Regulation}

\author{
Fabrizio Cafaggi \& Katharina Pistor
}

\begin{abstract}
:
This paper develops the normative concept of "regulatory capabilities", which asserts that nobody - individuals, groups or entities - should be subjected to a regulatory regime - public or private, domestic or transnational - without some freedom to choose. Choice in this context means the ability to accept or reject a regulatory regime imposed by others or to create an alternative one. A mere formal option is not sufficient; the freedom to choose requires real alternatives. The concept of regulatory capabilities has particular traction in the transnational context where private, hybrid public-private and public actors compete for influence, shape domestic regulation and in doing so limit the scope for democratic self-governance. It also helps illuminate the distributional effects of domestic regulation. As such, "regulatory capabilities" is a contribution to the general debate on the normative foundation of regulation and governance.
\end{abstract}

${ }^{1}$ We are grateful to the Scuola Superiore della Pubblica Amministrazione (SSPA) for funding this project, to participants at the workshop on "Dividing the Transnational Regulatory Space" held at Columbia Law School in September 2011 and to participants at the conference on "The Distributional Effects of Transnational Private Regulation" in Rome in May of 2012. Thanks also to all who have offered comments and suggestions at seminars and workshops at Harvard Law School, Columbia Law School and University of Pennsylvania Law School, and to four anonymous referees. Special thanks to Agnieszka Janczuk-Gorywoda and Casey Quinn for background research, tireless commenting, questioning and editing. All remaining errors are ours. 
I. Introduction: The Distributional Effects of Transnational Regulation

Transnational regulation affects individuals, groups and societies around the world; some is public, but in today's world much of it is private or hybrid. It can take different forms, including contracts, certification, safety or quality standards, as detailed in other contributions to this issue. The term 'private' regulation not withstanding, transnational private regulation (TPR) is not always purely private, but depends in many instances on explicit or implicit delegation of regulatory powers by states or international organizations to private parties ex ante, or the validation of private regulatory regimes by legislatures, courts or public regulators ex post. The purpose of public regulation is to create common rules that govern a specific issue or domain (food safety, finance, fair trade, etc.) and command compliance without express consent by those operating in the relevant domain. A purely private regulation requires consent, at least formally. Yet, as we will further discuss below, private regimes frequently compel compliance.

Establishing a regulatory regime entails defining the issues and actors that shall be regulated, the means and ends of regulation, access to rule making or amendment processes and sanctions for non-compliance. Every regulatory regime exerts differential effects on regulators, the direct targets of regulation (i.e. the regulated), its beneficiaries, as well as others who are indirectly affected by it. Regulation restricts the choices of some while enabling others to realize their preferences. As such, every regulatory regime has distributional effects. The 
key question addressed in this paper is what impact the rise of TPR has on the distributional effects of regulation, especially on the right to choose the rules by which one is governed.

Any regulatory regime affects the distribution of power and wealth. Establishing the rules of the game empowers rule makers to influence the allocation of costs and benefits associated with the regime. In the event that those framing the regulatory domain also participate in it they can stack the cards so as to expand their personal gains. The wealth and power effects of regulation are well established. The literature on regulatory capture, for example, has drawn attention to the fact that powerful interest groups frequently influence regulators and benefit from the rents or influence that regulation affords them (Stigler 1971; Ayres and Braithwaite 1999). There is a well-established literature in sociology on the power associated with framing issues and debates, largely concerning domestic issues (Dahl 1957; Bachrach and Baratz 1962; Lukes 1974), and an equally vibrant literature on framing power in global affairs (Rosenau 2002; Grant and Keohane 2005). With the expansion of the regulatory space from domestic to transnational and global relations, even greater benefits can be reaped from regulatory framing because of the sheer scale of transnational regulatory domains and the absence of transnational political institutions to check regulatory overreach.

We are not the first to note the expansion of transnational regulation, both public and private. Numerous scholars have analyzed the proliferation of new actors that wield power in the transnational sphere (Matthews 1997; Slaughter 2004; Grant and Keohane 2005; Cutler 2003) and the emergence of 'new global 
rulers' (Büthe and Mattli 2011; Cafaggi 2011; Mattli and Woods 2009b). Many commentators have offered a positive account of the rise of transnational regulatory networks as a way of transferring expertise and knowledge (Slaughter 2004) and as a challenge to the state's monopoly over regulation; some have even hailed the rise of a new, pluralist global world order (Matthews 1997). The focus of these studies on expertise and efficiency has meant that the distributional effects of globalized regulation have been left largely unaddressed (Mazower 2012). ${ }^{2}$ While there is a vibrant debate about democratic deficit in the European Union, including a shift from input to output legitimacy (Scharpf 1999), it is primarily concerned with public rather than private governance. 3 Public governance in turn has been contrasted with the experimental involvement of various stakeholders in the making and shaping of rules and regulations in Europe outside formal processes (Sabel and Zeitlin 2008). The "New Governance" (ibid) has been hailed as an alternative to public governance as it offers stakeholders direct and deliberative participation in problem solving.

Some of this literature is concerned with the questions we raise in this paper, namely who sets the rules for whom, who participates in rule making that affects others and whether those excluded from framing regulation are given an opportunity to express their choice ex post by deliberation, rule amendment or exit (Esty 2006; Black 2008; de Burca 2008). This literature offers rich insights into the emergence of new governance forms outside the state and the challenges they raise for legitimacy and accountability. Unlike the regulatory capabilities

${ }^{2}$ A partial exception is analyses of the impact of global public rules. Thus, Mattli and Woods analyze the distributional effects institutional context has on the ability of small elites to capture most of the gains. See (Mattli and Woods 2009a).

3 See, however, (Schepel 2005). 
approach, however, it does not stake a normative claim of the governed to selfdetermination and does not specifically address the distributional consequences of regulation.

The fact that transnational regulation is imbued with power and wealth effects has equally been recognized. As Grant and Keohane (2005) have shown, globalization has produced a range of new public, private and hybrid 'power wielders'. They demonstrate that these power wielders do not operate unconstrained but face a range of accountability mechanisms, including hierarchy, supervision, fiscal or funding constraints, market mechanisms, peer pressure and public reputational mechanisms (ibid at 36). Their primary concern is the potential for abuse of power. Our concern goes further, namely the denial of the right to self-governance. From this perspective, not all accountability mechanisms, even if effective in preventing abuse of power, are equal. Different accountability mechanisms empower different actors and embody different normative principles. Market mechanisms endorse economic value reflected in the market price and reward those willing and able to pay the highest price, whereas political mechanisms in principle give voice also to those who lack economic power. The 'pressure' that comes with political voice is the poor's last resort for drawing attention to their plight, as research on water management in the slums of Mumbai has demonstrated (Anand 2011). Lastly, market-based mechanisms tend to assume a given set of preferences - utility maximization in economic efficiency terms. Contesting a wider range of preferences and social goals requires a public space (Habermas and Lawrence 1991). 
This paper argues that the ability to choose regulation - the framing of a regulatory domain and the 'if' and 'how' of its regulation - is a value in itself. This normative position is derived from the basic principle of self-determination, which can be further divided into two components: (collective) democratic selfgovernance and (individual) private autonomy. Democratic self-governance empowers individuals to participate in collectively determining priorities for the society in which they live and the means for achieving them (Schmitter and Karl 1991; de Burca 2008; Diamond, Linz, and Lipset 1995). The principle of private autonomy endorses the idea that private parties (individuals or entities) are best positioned to determine their own preferences and to bargain over whose preferences might prevail (Smith 1976). By the same token it denies one party the right to unilaterally impose its preferred allocation of rights and responsibilities, costs and rewards, on another (Watt 2010).

Neither collective self-governance nor private autonomy is ever realized in pure form, but moderated by bargaining processes embedded with prevailing power and wealth relations. We thus do not argue for the full and unmitigated realization of self-determination in all regulatory domains. Instead, we seek to draw attention to the differential effect TPR exerts on the ability of people groups and communities within and across states - to choose the rules that govern them. We are particularly concerned with the possibility that TPR might systematically entrench the regulatory powers of some at the expense of others and impose regulatory regimes that were framed outside existing polities or with selective participation of only a few, and with the effects this might have on democratic self-governance. By stepping outside existing political structures 
some agents acquire a voice that reflects their economic and political power or expertise, but is incommensurate with the democratic principle of one-citizenone-vote. TPR also challenges private autonomy if it is used to grant some private actors the right to set the rules that others must follow absent effective bargaining processes on which the principle of private autonomy rests.

Moreover, TPR affects domestic polities establishing regulatory standards for sovereign states. Within the domestic realm states used to be the dominant regulator intruding into the private autonomy of citizens and economic entities (Majone 1994; Pildes and Sunstein 1995; Glaeser and Shleifer 2003). While state regulation typically operates next to private self-regulation in domains as diverse as family relations, financial trading platforms and the internet (Engle Merry 1988; Breton et al. 2009), the state has arguably been primus inter pares: it has the power to define the scope of permissible self-regulation, albeit subject to domestic constitutional and political constraints. With the rise of TPR, however, states have on occasion joined the ranks of the regulated by passing and implementing rules and standards that emanate from private regulators (Braithwaite and Drahos 2000).

An example of how private agents frame regulation to be endorsed and implemented by states is the international accounting standards devised by the International Accounting Standards Board (IASB) (Büthe and Mattli 2011). Another is the netting rules for derivatives 4 developed by the International Swaps and Derivatives Association (ISDA), which lobbied over fifty legislatures around

\footnotetext{
${ }^{4}$ Netting rules allow the counterparties to derivatives transactions to net their reciprocal claims outside the pool of assets used to satisfy all other creditors. They effectively sidestep the priority rules of bankruptcy codes in privileging parties to derivatives over other creditors. See (Morgan 2008).
} 
the world to change their bankruptcy codes to make them consistent with these netting rules. While these rules protect the complex contractual network of derivatives contracts, they create new risk for the financial system by accelerating downward trends (Roe 2011). As a matter of formal law sovereign states cannot be forced to comply with these rules. Private regulatory standards or guiding principles tend to be voluntary rather than mandatory; they are offered as models or best practices for a given regulatory domain; the primary sanction mechanism is the power of exclusion. In the absence of viable alternatives this, however, can be a powerful inducement. Similarly to TPR, soft law principles have found their way into multilateral organizations - the IMF or the World Bank - which frequently endorse them as 'best practice' standards recommended to client states requesting loans and/or policy advice. This third party enforcement has proven to be a powerful instrument in core areas of TPR, such as finance (IMF 2003) and rules governing business (Worldbank 2008).

The regulatory capabilities approach draws attention to the impact TPR has on the ability of individuals and collectives to determine the rules that shall govern them. We are not oblivious to the fact that TPR has many upsides. Rule by experts outside cumbersome political processes that are often burdened with veto players promises efficiency gains in rule making processes and regulatory outcomes (Slaughter 2004). If efficiency were the only, or indeed the preferred, norm that people around the globe value, TPR might not cause much concern. Irrespective of the process by which regulatory regimes were established, this outcome - if indeed achievable - could be said to justify its means. If, however, people have different preferences and values, efficiency claims alone cannot 
justify denying them an opportunity to express their own choice. Some may wish to trade efficiency for equality, sustainability or simply the freedom to choose and may be willing to accept the costs in reduced efficiency. We suggest that they should have the right to do so. Recognizing the right to choose in the context of regulation also offers an answer to democratic deficit debates: While a global democratic polity may be difficult to achieve, the normative principles enshrined in the idea of democratic self-governance could be advanced by embracing the notion of regulatory capabilities and developing institutional strategies for its realization.

The paper proceeds as follows: Section II below develops the regulatory capabilities approach; Section III discusses its inspiration, the individual capabilities approach; Section IV delineates capabilities from capacities; Section $\mathrm{V}$ analyzes how different modes of regulation affect regulatory capabilities. Section VI addresses strategies for developing and sustaining regulatory capabilities. Section VII concludes.

\section{Regulatory Capabilities: The Basic Concept}

Regulatory capabilities stands for the normative principle that individuals and collectives should have a choice as to what rules and regulations shall govern them. It is derived from the principle of self-determination. The principle of selfdetermination has traditionally been associated with the nation state and has been used to afford people claiming to be part of a single nation the right to form their own state and to choose its political order. In a world where nation states 
operate with substantial autonomy it makes sense to associate the right to selfdetermination primarily if not exclusively with statehood. In an increasingly interdependent world where rules created outside states demand compliance by citizens and entities within states, even by the states themselves, the concept needs to be reframed. In such a world the primary challenge to selfdetermination emanates from the proliferation of power wielders who, in pursuit of their own self-interest, disregard or are oblivious to others' freedom to choose. One concern is outright abuse of power; another is that those who control TPR processes will diminish the scope for regulatory capabilities of people subjected to their regimes.

The regulatory capabilities concept is meant to illuminate and assess deficiencies and potentials of TPR as concerns the freedom to choose the rules and regulations by which one is governed. It is has affinity with attempts to reconceptualize regulation in the domestic or regional realm by broadening input from various constituencies in the making and implementation of regulatory regimes as reflected, for example, in the notion of 'responsive regulation' (Ayres and Braithwaite 1992) and its cousin in European affairs, 'reflexive regulation' (De Schutter and Lenoble 2010). The regulatory capabilities approach shares with responsive regulation the deep commitment to democratic and republican principles, but it does not presume that all regulation emanates from the state or at most is delegated to non-state actors. Instead, it takes account of the fact that in the transnational sphere regulatory regimes emerge without explicit delegation by state actors. As such, the regulatory capabilities approach has greater affinity to concepts of reflexive governance, or the respect for other-regarding concerns 
in rule making and rule implementation. Yet, as will become clearer below, it places greater emphasis on creating the institutional conditions for individuals, collectives and entities to express their preferences, choose alternative forms of regulation or determine how best to govern interdependencies between different regulatory regimes. Lastly, the regulatory capabilities approach as affinity with the notion of "architecture of inclusion" as developed by Sturm (Sturm 2006). She argues that individuals realize their capabilities in large part as members of organizations - schools, universities, the work place, clubs and social organizations. Building inclusive architectures for these entities is therefore a critical step in enhancing individual capabilities. In a similar vein, we argue that the structure of transnational regulatory regimes is critical for the regulatory capabilities of those affected by them.

To develop the concept of regulatory capabilities, we first define the concept of regulation, identify the mechanisms of regulation and distinguish between regulators and the regulated. Regulation entails the standardization of a set of rules for a given domain - such as finance, food safety or environmental protection. Transnational regulatory domains can be established and sustained by different institutional mechanisms that empower some and disempower others, including public, private and hybrid ones. Purely public regimes result from state-to-state negotiation and are subject to ratification processes that subject them, in principle, to domestic political control. An example is the creation of a European anti-trust regime in the European Treaty, or the international free trade regime embodied in the World Trade Organization (WTO). Only countries that accede to the treaty in question are formally bound 
by the regime - even though multilateral treaties often exert effects on nonsignatories as well. Importantly, the accession process is determined not by international law alone, but in conjunction with the domestic constitutional requirements of the ratifying country. As such, the demoi in the acceding states exercise choice, at least in the formal sense.

On the opposite side of the spectrum are transnational regulatory regimes devised by private actors. Private actors may have political or economic reasons for advancing TPR as a means for achieving these goals. Prominent examples include the creation of product standards for global trade and accounting standards for firms (Büthe and Mattli 2011). Private TPR regimes frequently involve national public regulators, but this does not need to be the case.5 Other examples of private regimes are labeling and certification schemes for fair trade, organic products or environmental sustainability, further discussed below. Private regulators tend to establish standards for products or production processes and use private mechanisms - contracts - as the regulatory tool and certification for signaling actual compliance to consumers. Many of the goals transnational regulatory regimes pursue are well taken, even laudable. Yet, from the perspective of the regulatory capabilities approach the ends don't justify the means. Whatever goals private regulators might pursue, these goals may not be shared by those subjected to the regime: e.g., in the case of global production chains with suppliers or producers in far afield countries. Private regulation is frequently imposed through contractual mechanisms that in form, but not

\footnotetext{
5 Note that Büthe in this issue argues that regulatory regimes require a focal point and therefore limits his analysis to such regimes, which typically come with the endorsement of public national regulators.
} 
necessarily in substance, adhere to the principle of private autonomy. At face value they may involve an element of choice, but unequal bargaining power leaves the suppliers and producers with a take-it-or-leave-it option. Moreover, by imposing a single set of contracts on producers or suppliers in different countries these regimes can trigger processes of consolidation if not concentration of sectors in the economy as producers and suppliers seek out cost-efficient ways to meet the imposed standards. This can have far reaching implications on the structure of local economies and the relative bargaining power of local actors (Cata Backer 2007; Vandenbergh 2007). Yet, the standards themselves have never been vetted in a political process that allows for contestation and norm competition.

In between the purely public and the purely private regimes is a range of hybrid arrangements that combine public and private rule makers and regulators. The Basel Committee of Banking Supervisors (BCBS) discussed by Lall in this issue (see also (Simmons 2001)), for example, brings together (public) regulators from select countries - formerly the $\mathrm{G} 7$, now the $\mathrm{G} 20$ - to determine the standards of prudential regulation for internationally active banks. Regulators have formal jurisdiction within the territory of their nation state. Yet, the collective of national regulators admitted to the BCBS - membership being determined by the most powerful actors in the club ${ }^{6}$ - effectively establishes prudential standards for every country wishing to join global financial markets; financial intermediaries from countries that do not comply with these standards

\footnotetext{
${ }^{6}$ The decision to expand the club was made in the aftermath of the global financial crisis and announced by then President George W. Bush.
} 
face exclusion from global financial centers (Kapstein 1996). The rules and regulations BCBS adopts have far reaching implications well beyond the national regulators that take part in the rule making process. BCBS frames domestic financial regulation and as such allocates the costs for regulatory failure to different constituencies. BCBS consults with global financial intermediaries, including the Institute for International Finance (IIF), but the customers of financial intermediaries and taxpayers who will have to bail them out in the event of market and/or regulatory failure are absent from this process. Critically, these stakeholders rarely exercise much voice at the legislative or implementation stages in their home jurisdictions either. As Lall emphasizes, the non-public nature of the bargaining process at the BCBS rules out public contestation and ensures that bargains struck early in the process become sticky.

TPR can also result from a single country unilaterally establishing standards for those wishing to engage with customers on its territory. This protects the sovereignty of the standard setting country and the voice of its citizens, but at the expense of countries that house producers and suppliers that become rule takers, not rule makers. The food safety standards that govern global food chains are established by major importers, such as the United States and the European Union, without much regard for the effects they might have on producers, suppliers or the economic structures of exporting countries (DeSchutter 2013). Private entities (typically corporations headquartered in importing countries) transmit these standards to producers and suppliers by way of private contracts. Only those willing and able to comply with these standards find buyers for their products in international markets. This is not an argument against food safety 
standards in general, or private food safety standards in particular. It is to point out that standards can be set and enforced in different ways. They can be more or less attuned to local conditions in exporting countries and impose more or less costs on producers and suppliers. In the absence of choice for suppliers and producers, economies of scale that benefit major importers will invariably trump these other concerns. Local or national governments, and potentially other intermediaries, can enhance the voice of producers and suppliers if they insert themselves in the negotiation of compliance requirements and help organize local voice. The principles set forth by the Roundtable on Sustainable Soy, for example, binds those participating in a supply chain to respect local agricultural practices and engage in a dialogue with local communities about how best to preserve them.7

In each of the above cases one can detect an element of choice. The Basel Accord, for example, does not have direct legal effect in countries around the world, but has to be incorporated into domestic legislation to become legally effective. International accounting standards need to be endorsed by local regulators to avoid the costs associated with duplication. Ex ante state delegation as well as ex post state ratification and state validation of private contracts all play a critical role in these regimes. But the choice is more often than not a simple take-it-or-leave-it option. Rejecting the regime on offer implies exclusion not only from regulatory domains but also from the markets they regulate.

\footnotetext{
${ }_{7}$ See principle 3 of Roundtable for Sustainable Soy, available at www.rss.org. Last visited 20 March 2013.
} 
Every regulatory regime gives more voice to some than to others and as such has distributional consequences. From the perspective of regulatory capabilities the critical question is whether these effects are random or systemic in the sense that they predictably deny certain constituencies their right to regulatory selfdetermination. Equally important is the openness of regulatory regimes to future contestation. The reach of regulatory regimes changes over time and exerts differential effects on different people, many of which may be difficult to foresee at the outset. From the perspective developed here only regimes that are open to correction and adaptation, i.e. those that remain contestable live up to the normative standards of regulatory capabilities.

\section{From Individual to Regulatory Capabilities}

The term regulatory 'capabilities' is inspired by the work of Amartya Sen and Martha Nussbaum on individual capabilities. Sen has long questioned the almost universal acceptance of wealth creation as the primary if not exclusive goal of economic development (Collier 2007) and has instead placed freedom at the center of development. Wealth is a means for, but individual freedom is the end of development (Sen 1999). Importantly, freedom cannot be assumed. Conditions for individuals to pursue their individual freedom are human-made, or socially constructed, and as such contingent on political choices that are embodied in law, institutions and organizational practices. The individual capabilities approach thus shifts the focus from the protection of negative freedoms against the state to the conditions for individuals to choose the lives they have reason to value (Sen 
1999). From this perspective even the most negative rights - property, free speech, religious freedom, etc. - acquire a positive connotation: they too are contingent on social conditions.

While Sen contends himself with the broad concept of individual capabilities and justifies its open-ended nature as a reflection of pluralism, Nussbaum has gone a step further and developed a list of 'central' individual capabilities (Nussbaum 2003). They include, among others, the ability to lead a normal life, preserve one's bodily integrity, engage in practical reasoning, associate and live with others. ${ }^{8}$ These central capabilities constitute a basic normative threshold for societies to be deemed just without identifying them with a single mode of institutional realization (Nussbaum 2011, p. 40). Only societies that put all their members in a position to realize these capabilities - i.e. enable them to achieve minimum levels of education, protect them from harm and give them access to health care, nourish institutions and organizations that foster different forms of affiliation, among others - can be called just (Nussbaum 2011).

The capabilities approach's focus on actual attainments has led some to argue that it is primarily if not exclusively outcome-oriented. Yet, Sen distinguishes between agency and well-being freedom, where the former relates to the freedom to choose and only the latter to outcomes. ${ }^{9}$ The argument also overlooks the

\footnotetext{
${ }^{8}$ Nussbaum defines the relationship between practical reason and capabilities as follows: "The opportunity to plan one's own life is an opportunity to choose and order functionings corresponding to the other various capabilities". See (Nussbaum 2011, 39) .

9 In relation to agency freedom he recognizes that there is a complex relationship between choice and freedom and that one should not give for granted that there is always a positive correlation between the two. In fact it might very well be that a conflict between the two can arise. See (Sen 1992, 56) where he states: "Freedom is a complex notion. Facing more alternatives need not invariably be seen as an expansion of a person's freedom to do the things he would like to do... the expansion of choices to be made is both an opportunity (the choices can be made by oneself) and a burden (the choices have to be made by onself)." Ibid at 63 .
} 
central role institutions play within the capabilities framework. Individual choice is determined not exclusively by individual preferences or endowments, but by the availability of capability sets as defined by institutional arrangements, both public and private. ${ }^{10}$ Individuals' abilities to exercise their freedoms are therefore in large measures dependent on proactive intervention. Freedom of speech requires command of a language as well as literacy, and by implication education; so does the ability to participate in social and political life. The critical question for a capabilities analysis is therefore whether individuals are put in a position to choose the lives they value. This implies that within this framework outcome is contingent on institutional prerequisites. These institutional prerequisites result from collective choice.

Who then bears the obligation to enable individuals to choose? In the past the answer to this question has been predominantly the society or state of which the individual is a member or citizen. The nation state continues to play a critical role in providing the preconditions for justice even in the age of globalization (Nussbaum 2011). Still, the rise of transnational governance means that many conditions that affect an individual's capabilities are created outside and out of the control of his or her domestic polity. It follows that this polity no longer bears exclusive responsibility for social justice. That responsibility, we argue, is shared with rule makers beyond its shores. In the case of TPR the responsibility for individual capabilities therefore does not lie exclusively with states. Instead, the instigators of TPR - that is, the foreign certification bodies, the global rulers for

\footnotetext{
${ }^{10}$ In the words of Marth Nussbuam, "combined capabilities are defined as internal capabilities plus the social/political/economic conditions in which functioning can actually be chosen...”. See (Nussbaum 2011, 22).
} 
financial and accounting standards and the multinational standard transmitters - share a responsibility. This responsibility is to the individual as well as to organized groups that are subjected to TPR.

Even when there is widespread agreement about the goals of regulation - the prevention of nuclear, financial or health disasters, for example - there may still be disagreement about how best to achieve them and about the allocation of the costs of regulation as well as those of possible regulatory failure. It may be rational for every regulator, whether public or private, to externalize these costs to others beyond its respective sphere of accountability. However, in an interdependent world externalization can only be partial or temporary and can easily escalate into a system-wide crisis. Interdependence has become the hallmark of our age of globalization. Domestic economies are deeply integrated with global production chains, financial markets and transport systems. Actions and events in one part of the global system sooner or later affect other parts. The global financial crisis has amply demonstrated that 'de-coupling' is possible only for those countries that have abstained from integration with the global system (Cetorelli and Goldberg 2011).

Lambin et al (2011) identify four different modes of interdependence: displacement, rebound, cascading and remittance. Each is associated with effects institutional and regulatory change can have far from where the change took place. Specifically, displacement stands for the migration of activities from one place to another; the rebound effect for cost reducing improvements such as technological or institutional change that may, contrary to expectations, increase rather than decrease harmful activities; the cascade effect for "a chain of events 
due to a perturbation affecting a system" (ibid at 3468); and the remittance effect for the possible negative effects of resource transfers on previously unsustainable practices in the recipient location. To address these varying effects of interdependencies, which are difficult to anticipate ex ante, groups and communities that will be negatively affected by them should be enabled to act upon them. This requires local information gathering, local regulatory capacity and the collective ability to respond to threats posed to the community. Communities that are consistently denied and therefore lack the ability to collectively choose the rules that shall govern them will be unable to respond to new challenges as they arise.

\section{Regulatory Capabilities vs. Regulatory Capacity}

A distinction must be drawn between the regulatory capabilities approach and the notion of regulatory capacity, one that parallels the distinction between individual capabilities and individual capacity. Many individuals are unable to enhance their own wellbeing or that of others. They lack the education, training, information or resources to do so. This may have different causes. Individuals may choose leisure over study and may devote their attention, time and resources accordingly. Alternatively, conditions may be absent for enabling individuals to make such choices in the first place. If there are no schools, or girls are barred from attending them in accordance with social norms, the end result is the same. They will lack the capacity to successfully solve math problems. Importantly, however, they lack this capacity not because of their own choice, but because they 
were denied the individual capability to make choices about the life they have reason to value. Understanding the cause of the lack of capacity is critical for designing effective remedies. It makes little sense to train teachers in math and build new schools if prevailing social institutions prevent girls from taking math classes (Banerjee and Duflo 2012). If, in contrast individuals are enabled to make choices, but happen to make 'wrong' choices, incentive schemes or training to help them do better can make a difference.

The same reasoning applies to the distinction between regulatory capacity and capabilities in the realm of collective decision making for determining the rules by which groups or communities shall be governed. Regulatory capacity depicts the presence of the requisite skills and resources, including information gathering and management systems (Esty 1999) for maintaining or complying with regulatory regimes irrespective of who devised them. Many development agencies seek to enhance the skill sets or capacities of constituencies in less developed countries to enable them to comply with existing rules and regulatory regimes, because of their presumed superiority or because they operate as effective entry barriers to participating in global markets. An example of the former is the International Monetary Fund's Financial Sector Assessment Program (FSAP) in response to the East Asian financial crisis (IMF 2003; Pistor 2002). Rules and regulations from selected countries were compiled into best practice standards that were used to assess regulatory regimes found elsewhere. The underlying assumption was that the first set of rules was indeed superior and that other countries would benefit from mimicking them it developing the regulatory capacity to implement it effectively. Each country surveyed received 
recommendations and technical advice to increase its capacity to comply with these standards. Similarly, the Inter-American Development Bank (IDB) has developed tool kits to train farmers in Latin America to produce flowers, fruits and vegetables that can be exported to the United States. Compliance with these standards is an entry condition to this important market. Finally, nongovernmental certifiers train local producers in countries around the globe in production strategies that qualify them for certification as 'fair trade' or 'organic'.

The concept of regulatory capabilities differs from regulatory capacity in that its emphasis is less on skills or compliance with regulatory standards set by others, but on the ability to choose among different regimes and to develop alternatives. This requires a shift of attention from regulatory compliance to the process of collective decision making. If choice is encouraged rather than suppressed, local constituencies may well design sets of regulations that are both effective and reflect local preferences. Indeed, the global financial crisis has demonstrated that financial regulators that established counter-cyclical standards or adopted capital controls better weathered the fallout from the crisis - which ironically originated in the very countries that had served as bestpractice standards for financial regulation (Hahm et al. 2012). Similarly, producers might well develop alternative strategies for making food safe for export that reflect their own priorities even as they meet the standard ultimately set by the Food and Drug Administration (FDA) in the US (De Schutter 2013).

That such an approach is feasible, at least in principle, is demonstrated by the EU's "New Approach" for regulatory standard setting. EU level directives specify general regulatory standards; EU level regulatory bodies with input from national 
regulators add details on how to meet them; the implementation is ultimately left to local actors who select specific regulatory means. This approach has been used with varying success in different regulatory domains, including finance and food safety. ${ }^{11}$ Specifically, in the case of food safety the implementation of EU level standards leaves substantial discretion about the choice of instruments not only to legislatures and regulators, but also to producers.

In the transnational context facilitating collective decision making with the goal of enhancing regulatory choice for multiple constituencies faces particular problems. With the exception of supra-national entities such as the EU, common polities, entities or organizations that facilitate collective decision making are largely absent; those subjected to or affected by regulation are often widely dispersed and lack a common language or institutions to coordinate their preferences and actions. In contrast, private regulators, especially those industryled, are fewer in numbers, well resourced, often well organized and tend to have strong incentives to impose their preferred regime on different constituencies irrespective of local preferences. They are primarily interested in regulatory compliance and are thus willing to invest in capacity building. However, they tend to be less interested in regulatory capabilities as this might disrupt their quest for economies of scale a uniform standard affords them. A different case concerns NGO-led regimes where local specificities and affected communities often constitute, at least in theory, a significant concern.

\footnotetext{
${ }^{11}$ For finance see the Lamfalussy process (2001); critically (Vander Stichele 2008). For food safety see EU Directive 2001/95 on general product safety chapter II, esp. Arts. 3 and 4.
} 


\section{Modes of Regulation and Regulatory Capabilities}

Regulatory capabilities are not given but must be created or developed. At a minimum this requires removing obstacles to choice; at a maximum anybody directly or indirectly affected by a regulatory regime should have a say in its design irrespective of his or her resources, political influence or location. The latter is an ideal, not a claim that this state of the world might ever be realized. The same reasons that make direct democracies in most contexts an aspiration rather than a reality apply here - and arguably with even greater force given the absence of an institutionalized global polity. Yet, while individual voice may be impossible to realize, with the right institutional arrangements collective choice is achievable in many instances; and where this should prove to be unattainable an effective exit option is still superior to facing a monopoly regulator.

A single agent who controls access to a market can demand monopoly rents. So can monopoly regulators, whether public, private or hybrid, when they generate regulatory rents and reduce others' freedom of choice (Keohane and Victor 2011; Overdevest and Zeitlin 2013). Monopoly regulators deprive others of their regulatory capabilities by demanding compliance and investment in specific skills that ensure compliance. This leaves little room for experimenting with alternative regulatory approaches that might better reflect the preferences and goals of the regulated or others affected by the regime. In the extreme it can undermine the ability of the regulated to formulate their own regulatory preferences and develop the means or required skill sets for meeting them. 
The major argument for a single regulatory regime is that it reduces transaction costs and that an effective standard would benefit all..$^{12}$ Even if a single effective standard is within reach, its establishment entails switching costs that create distributional effects. Moreover, any regulatory regime will require adaptation over time, which raises the question who decides and whose interests should be considered when making such decisions. Last but not least, as noted earlier, the ability to choose is a value in itself and should not be disregarded lightly. Regulatory monopolies that command exclusivity are therefore prima facie suspect from the normative perspective of regulatory capabilities.

Consider the global food supply chains discussed by Olivier De Schutter in his contribution to this issue (2013). They constitute an integrated regulatory regime for food quality and safety from producers and suppliers to exporters, importers, whole and retail sellers and finally consumers. The dominant regulatory tool within the chain is contracts, anchored in public regulations of the importing country. As detailed by De Schutter, the rise of TPR has gone hand in hand with a remarkable consolidation in this sector, with large importers and exporters controlling access to global markets, squeezing out small producers and suppliers. This outcome might be regarded as the natural product of competition, where superior organizational forms - global supply chains - weed out inferior ones. However, survival or dominance may also result from unequal bargaining power or greater resources that advantage some over others in dividing up the transnational regulatory space. Once established, the first mover advantage

\footnotetext{
${ }^{12}$ The superiority of a hierarchical single regime has been recently challenged by recognizing the potential benefits of complex regimes. See (Keohane and Victor 2011) and (Sabel and Simon 2012).
} 
associated with standard setting generates increasing returns, which makes future change difficult if not impossible irrespective of the standard's quality (Lall 2013).

Another example of regulatory monopolies is the standards for "good manufacturing practices" and "good clinical practices" for pharmaceuticals promulgated by the International Conference on Harmonization (ICH) (Berman 2013). Public regulators and private companies from three polities - the US, the EU and Japan - have joined force and created common regulatory standards in an attempt to facilitate trade and minimize entry barriers. Representatives from other countries can be granted observer status but have no actual say in the standard setting exercise. ICH standards have effectively become global standards; producers wishing to export to markets represented by ICH must comply. This is costly and many producers have been unable to do so. The introduction of ICH standards in China, India, Romania and other emerging markets has resulted in the closure of many smaller producers of pharmaceuticals (ibid). If these standards were the only viable option to ensure the safety of pharmaceuticals, this outcome would be inevitable. However, it is at least feasible that other standards ensure safety and are less costly for potential competitors. ICH's regulatory oligopoly restricts access to markets; it also restricts alternative regulatory options and thus impedes regulatory capabilities in the countries affected by it, i.e. all that house pharmaceutical companies that wish to access markets in the US, EU and Japan.

Market control is just one path to regulatory monopoly. Another is the network effect: An individual or entity may opt into a regulatory regime to benefit from 
the fact that many others have done so already. Here too, others have made regulatory choices; the difference is that the decision to join is based on interest alignment rather than conflict. Still, closer scrutiny suggests that in many instances network effects are indistinguishable from classic monopolies; the outcome may even be worse because the costs of leaving a network may preclude change even if the majority of network members so desires. Examples of regulatory network effects are regional payment systems, which must be interoperable for payers, intermediaries and final recipients. The adoption of common standards within the European Union was fraught with tension as industries in different countries had established different standards and were expected to lose if standards with "winner takes all" qualities (David and Greenstein 1990) were chosen. In the European context there was substantial deliberation and stakeholder involvement. However, the global wholesale payment system, which was established by the leading central banks in consultation with their domestic financial industry, but not with regulators or regulated in other countries that sought access to the system (DeRosa 2013).

Other TPR regimes display varying degrees of choice. Auld et al (2013) distinguish between control and empowerment regimes: the former are characterized by strict guidelines that are centrally monitored and enforced, the latter by more decentralized, even reciprocal relations of monitoring and learning (Sabel 1995). Labeling regimes for fair trade and certification for organic production provide interesting material for comparing the evolution of regimes and their effect on regulatory capabilities over time. The Fair Labeling Organization (FLO) began as an in-house process for assessing production 
conditions and offering consultations for improvement. Over time it was increasingly centralized, first with the creation of an in-house independent committee followed by the establishment of a separate entity in charge of monitoring compliance and ensuring consistency. The major driver for this change, according to Auld et al., was the threat of legal liability from market actors. They challenged the denial of a fair trade label to them on the grounds that small producers in developing countries obtained them because different standards were applied to them and that this constituted unfair, discriminatory treatment. Leaving aside whether the legal challenge would have been successful, the FLO exhibited strong litigation-risk aversion, with negative distributional effects for those unable to meet the new uniform standards. Certification programs for organic produce evolved in a similar fashion (Auld, Renckens, and Cashore 2013; Arcuri 2013). At the outset, organic producers around the world created the International Federation of Organic Agricultural Movements (IFOAM) to facilitate sharing of information about organic production and cultivation processes among its members. Monitoring was originally devised as a two-way process that involved advice and technical assistance for improvements consistent with diverse local conditions. Over time, the process became increasingly formalized, and the accreditation and certification programs have now been institutionalized as the International Organic Accreditation Service (2006). Arcuri (2013) argues in this issue that the evolution from a federation targeted at producers into a global accreditation system has gone hand in hand with the 'publicization' of private regulatory regimes, i.e. their incorporation into public law. In a parallel development, organic farming became industrialized, and 
these processes jointly resulted in a weakening of organic standards (ibid). The original movements' founders, the small-scale farmers, were increasingly marginalized in this process as bigger actors assumed an active role in the formulation of standards and the lobbying of legislatures. These two examples do not add up to proof that attempts to design regulatory regimes with a goal of enhancing regulatory capabilities will be pushed aside by competition or lobbying to give way to more centralized structures. But they do suggest that for regimes that endorse regulatory capabilities to survive, more is needed than good intentions at the outset.

\section{Developing and Sustaining Regulatory Capabilities}

The foregoing analysis raises the question how best to develop and sustain regulatory capabilities in the transnational setting. The analysis that follows is necessarily abstract as we lack systematic data about regulatory capabilities enhancing regimes and their evolution over time. Nonetheless, some important inferences can be drawn from contributions to this special issue, other case studies and related literatures that grapple with modes of governance beyond states and markets (Ostrom 2010; Powell 1990; de Burca 2008).

Our concern is with the initial design of regulatory regimes that enhance regulatory capabilities and their sustainability. The concept of self-determination as used in this paper is not limited to an initial decision to create a regime, but extends to the continuing contestability of the regime by those affected by it. Participating in the initial design of the regime creates a presumption of choice, 
but no more. Regimes that evolve to restrict regulatory capabilities to only the regulators or deny some critical constituencies voice and/or exit rebut that presumption. The main beneficiaries of regulatory capabilities may change over time as some gain and others lose access to rule setting. Yet, as Nussbaum has pointed out, only a society that enables all its members to develop their individual capabilities (see supra) is a just society. In a similar vein, only a just regulatory regime must promote regulatory capabilities for all. At a minimum, regulatory regimes that deny regulatory capabilities systematically to certain constituencies must be deemed unjust.

With these principles in mind we turn to the question of how to develop and sustain regulatory capabilities. The analysis in the previous section suggests first, that monopoly regulation is prima facie objectionable from a regulatory capabilities approach; and second, that regulatory approaches that enhance regulatory capabilities are possible, but often fragile. It follows that enabling conditions are needed not only for establishing regulatory regimes conducive to regulatory capabilities, but also for sustaining them over time.

The case studies on fair trade and organic production by Auld et al. and Arcuri suggest that regulatory capabilities enhancing regimes can arise spontaneously. This is possible when similarly situated actors create member-based regulatory regimes that bring together regulators and regulated to achieve a common goal, such as fair trade or organic agricultural practices. Importantly, such regimes have been created among geographically dispersed actors with very different capacities in achieving the common goal. The insights from these case studies are supported by research on polycentric governance regimes (Ostrom 2010). 
Extensive case studies and lab results suggest that collective governance "beyond states and markets" is feasible when actors can communicate with one another, rely on reputational bonds, have viable exit options yet share a longer-term horizon, have high marginal capital return and agree on sanctions (ibid).

This analysis helps explain why the regulatory capabilities enhancing original regimes were not sustained over time. The initial organization of these regimes was based on commonality of goals; it facilitated communication among participants and provided for sanctioning regimes as well as exit options. However, competition in product markets shortened the time horizon and eroded cooperation. Moreover, differential access to public law makers (in the case of organic food production in the US) allowed some to promote alternative goals that exhibited larger economies of scale for themselves and prompted them to defect.

At a more general level this raises the question whether competition is compatible with regulatory capabilities: Where the market principle determines winners or losers, few actors have incentives to invest in capabilities of their potential competitors. Even if they might benefit from this in the long term - as suggested by the literature on contracting for innovation (Gilson, Sabel, and Scott 2009), and also the discussion supra about the need to address interdependencies - competition tends to shorten the time horizon for costbenefit analyses and creates incentives for defecting in search of short-term gains.

Still, extensive cooperation is feasible under conditions of competition if mediated by a quasi-neutral agent. In his analysis of networks as social 
organizations between hierarchy and markets, Woody Powell argues that such an "anchor tenant" should have a vested interest in the common goal13 without standing in direct competition to other participants in the network (Powell 1990; Powell 2010). The major function of this anchor tenant is to keep all eyes on the common goal and mediate conflicts between relevant parties, whose willingness to participate in the mediation clearly depends on their expected gains from collaboration. The anchor tenant has an interest in mediating competing objectives of other participants to ensure a positive outcome. The other participants will yield if and when their expected returns of staying in the regime exceed the costs of exit, which exclude not only the actual costs of leaving a regime, but also of being excluded from and the need to create an alternative one.

Such an anchor tenant may be the government of a nation state that brings together local producers, exporters and foreign importers as in the case of South Africa's intervention in global food production chains (see De Schutter in this issue), or a multi-lateral institution such as the World Bank or a regional development bank. The European Bank for Reconstruction and Development (EBRD), for example, played a critical role in mediating the management of the financial crisis for countries in Central and Eastern Europe. It convened regulators, supervisors and finance ministers from home and host countries of banks in the region to prevent a financial collapse. With only minimal principles of conduct - a commitment not to withdraw capital in an uncoordinated fashion and the right to be heard - and a commitment to make public the commitments made, it was able to achieve cooperation in a situation where most of the larger

${ }_{13}$ This is why it is a quasi-neutral, not entirely neutral agent. 
players had strong incentives to defect (Pistor 2011). While it is too early to assess the longer term sustainability of this particular regime (EBRD 2011), the "Vienna Initiative' demonstrates that multilateral organizations can play a critical role in inducing cooperative behavior and other-regarding preferences -- a first step towards enhancing regulatory capabilities. This analysis also draws attention to the fact that the internal architecture (Sturm 2006) of international organizations and other entities is crucial for their role as effective anchor tenant. In particular, the EBRD drew strength from its role as a fairly small actor with extensive ties to both the private and public sector and a reputation of acting as a neutral arbiter (Pistor 2011).

A mediating agent or anchor tenant might also play an important role where regulatory capabilities enhancing regimes face defection or creeping monopolization by mediating disputes and developing compromise solutions, such as conditional or temporal exemptions from regulatory standards. It might also help organize constituencies to contest a defector's attempt to gain competitive advantages by lobbying for state backing of his monopoly regime.

This raises interesting questions as to the design characteristics of such an agent, a question that can be answered in the abstract but depends on the nature of the regime, its scope and the identity of the regulators, the regulated, other beneficiaries and potential victims of the regime. This will have to be left to future research. By highlighting the potential of mediating agents to promote regulatory capabilities enhancing regimes we hope to show that regulatory selfdetermination does not necessarily require a fully integrated polity. Instead, domain specific mediators may be a promising solution. 


\section{Concluding Comments}

The regulatory capabilities approach calls attention to the fact that regulation entails distributional effects not only in terms of power and wealth but also with regard to the right to self-determination for individuals and communities. There is more than one way to regulate most issues, and some strategies offer greater freedom to choose for more constituencies than others. This may increase the transaction costs of regulation, but costs alone should not justify the curtailment of the right to self-determination, which is a fundamental expression of freedom. This paper has argued that the collective right to self-determination should not be confined to nations or statehood. In an increasingly interdependent world where multiple actors assume regulatory powers over others, self-determination must be redefined as the right to choose the rules by which one is governed and must ensure the respect of others' choices in more general terms. We are only seeing the beginnings of attempts to institutionalize this principle and it is too early to say whether these experiments will be successful in the long term. The goal of this paper was not to demonstrate that this would be an easy task, but instead to put regulatory capabilities as a normative principle at the center of the debate about transnational regulation, in particular TPR. 
References

Anand, Nikhil. 2011. "Pressure: The PoliTechnics of Water Supply in Mumbai." Cultural Anthropology no. 26 (4):542-564.

Arcuri, Alessandra. 2013. "The Transformation of Organic Regulatoin: The Ambiguous Distributional Effects of "Publicization"." This Issue.

Auld, Graeme, Stefan Renckens, and Benjamin Cashore. 2013. "Transnational Regulation between the Logics of Empowerment and Control." This Issue.

Ayres, I., and J. Braithwaite. 1999. "Tripartism - Regulatory Capture and Empowerment." Law and Social Inquiry no. 16 (3):435-496.

Ayres, Ian, and John Braithwaite. 1992. Responsive Regulation. Oxford: Oxford University Press.

Bachrach, Peter, and Morton S. Baratz. 1962. "The Two Faces of Power." American Political Science Review no. 564947-952.

Banerjee, Abijit, and Esther Duflo. 2012. Poor Economics: A Radical Rethinking of the Way to Fight Global Poverty: Public Affairs.

Berman, Ayelet. 2013. "The Distributional Effects of Transnational Pharmaceutical Regulation." manuscript on file with the authors.

Black, Julia. 2008. "Constructing and Contesting Legitimacy and Accountablity in Polycentric Regulatory Regimes." Regulation \& Governance no. 2 (2):137-164.

Braithwaite, John, and Peter Drahos. 2000. Global Business Regulation. Cambridge: Cambridge University Press.

Breton, Albert, Anne Des Ormeaux, Katharina Pistor, and Pierre Salmon. 2009. Multijuralism: Manifestations, Causes and Consequences. Williston VT: Ashgate.

Büthe, Tim, and Walter Mattli. 2011. The New Global Rulers: The Privatization of Regulation in the World Economy. Princeton: Princeton University Press.

Cafaggi, Fabrizio. 2011. "New Foundations of Transnational Private Regulation." Journal of Law and Society no. 38 (1):20-49.

Cata Backer, Larry. 2007. "Economic Globalization and the Rise of Efficient Systems of Global Private Lawmaking: Wal-Mart as Global Legislator." University of Connecticut Law Review no. 39 (4):1739-1784.

Cetorelli, Nicola, and Linka S. Goldberg. 2011. "Global Banks and International Shock Transmission: Evidence from the Crisis." IMF Economic Review no. $59(1): 41-76$.

Collier, Paul. 2007. The Bottom Billion: Why the Poorest Countries are Failing and What can be Done about it. Oxford: Oxford University Press.

Cutler, Claire. 2003. Private Power and Global Authority: Transnational Merchant Law in the Global Political Economy. Cambridge: Cambridge University Press.

Dahl, Robert. 1957. "The Concept of Power." Behavioral Science no. 2 (3):201215.

David, Paul A., and Shane Greenstein. 1990. "The Economics of Compatability Standards: An Introduction to Recent Research." Economics of Innovation and New Technology no. 1:3-41. 
de Burca, Grainne. 2008. "Developing Democracy Beyond the State." Columbia Journal of Transnational Law no. 46 (2):221-278.

De Schutter, Olivier. 2013. "Power and Price: The Governance of Food Chains in a Globalized World." This Issue.

De Schutter, Olivier, and Jacques Lenoble. 2010. Reflexive Governance: Redefining the Public Interest in a Pluralistic World. Oxford and Portland, OR: Hart Publishing.

DeRosa, David. 2013. "Sponsored Transactional Patterns: Comments on Mehrling's "Essential Hybridity: A Money View of FX"." Journal of Comparative Economics no. 41 (2).

DeSchutter, Olivier. 2013. "Competing for Standards in Global Food Supply Chains." This Issue.

Diamond, Larry, Juan J. Linz, and Seymour M. Lipset. 1995. "What Makes for Democracy?" In Politics in Developing Countries: Comparing Experiences with Democracy, edited by Larry Diamond, Juan J. Linz and Seymour M. Lipset, 1-57. London: Boulder.

EBRD. 2011. Vienna Initiative - Moving to a New Phase. London: European Bank for Reconstruction and Development.

Engle Merry, Sally 1988. "Legal Pluralism." Law and Society Review no. 22 (5):867-896.

Esty, Daniel C. 1999. "Toward Optimal Enviornmental Governance." New York University Law Review no. 74:1495-1574.

---. 2006. "Good Governance at the Supranational Scale: Globalizing Administrative Law." Yale Law Journal no. 115 (7):1490-1562.

Gilson, Ronald J., Charles F. Sabel, and Robert E. Scott. 2009. "Contracting for Innovation: Vertical Disintegration and Interfirm Collaboration." Columbia Law Review no. 109 (3):431-502.

Glaeser, Edward, and Andrei Shleifer. 2003. "The Rise of the Regulatory State." Journal of Economic Literature (June):forthcoming.

Grant, Ruth, and Robert O. Keohane. 2005. "Accountability and Abuses of Power in World Politics." American Political Science Review no. 99 (1):29-43.

Habermas, Jürgen, and Frederick (transl.) Lawrence. 1991. The Structural Transformation of the Public Sphere: An Inquiry into a Category of Bourgeois Society. Cambridge: MIT Press.

Hahm, Joon-Ho, Frederic S. Mishkin, Hyun Song Shin, and Kwanho Swin. 2012. "Macroprudential Policies in Open Emerging Markets." NBER Working Paper no. 17780.

IMF. 2003. International Standards: Strengthening Surveillance, Domestic, Institutions, and International Markets. Washington: International Monetary Fund.

Kapstein, Ethan B. 1996. Governing the Global Economy: International Finance and the State. Cambridge, MA: Harvard University Press.

Keohane, Robert O., and David G. Victor. 2011. "The Regime Complex for Climate Change." Perspectives on Politics no. 9 (1):7-23.

Lall, Ranjit. 2013. "Timing as a Source of Regulatory Influence: Winners and Losers in Global Finance." Regulation \& Governance no. This Issue. 
Lambin, Eric F., and Patrick Meyfroidt. 2011. "Global land use change, economic globalization, and the looming land scracity." PNAS no. 108 (9):34653472.

Lamfalussy, Alexandre. 2001. Final Report of the Committee of Wise Men on the Regulation of European Securities Markets. Brussels: European Union.

Lukes, Peter. 1974. Power: Radical View. London: Macmillan.

Majone, Giandomenico. 1994. "The Rise of the Regulatory State in Europe." West European Politics no. 17 (3):77-101.

Matthews, Jessica. 1997. "Power Shifts." Foreign Affairs no. 76 (50-66).

Mattli, Walter, and Ngaire Woods. 2009a. "In Whose Benefit? Explaining Regulatoroy Change in Global Politics." In The Politics of Global Regulation, edited by Walter Mattli and Ngaire Woods, 1-43. Princeton: Princeton University Press.

---. 2009b. The Politics of Global Regulation. Princeton: Princeton University Press.

Mazower, Mark. 2012. Gvoerning the World: The History of an Idea. New York: Penguin Press.

Morgan, Glenn. 2008. "Market Formation and Governance in International Financial Markets: The Case of OTC Derivatives." Human Relations no. 61:637-66o.

Nussbaum, Martha. 2003. "Capabilities as Fundamental Entitlements: Sen and Social Justice." Feminist Economics no. 9 (2-3):33-59.

---. 2011. Creating Capabilities: The Human Development Approach. Cambridge, Mass: Belknap Harvard.

Ostrom, Elinor. 2010. "Beyond Market and States: Polycentric Governance of Complex Economic Systems." American Economic Review no. 100 (June):641-672.

Overdevest, Christine, and Jonathan Zeitlin. 2013. "Assemblingl and Experimentalist Regime: Transnational Governance Interactions ni the Forest Sector." Regulation \& Governance no. (forthcoming).

Pildes, Richard H., and Cass R. Sunstein. 1995. "Reinventing the Regulatory State." Chicago Law Review no. 62 (1).

Pistor, Katharina. 2002. "The Standardization of Law and Its Effect on Developing Economies." American Journal of Comparative Law no. 50:101-134.

---. 2011. "Governing Interdependent Financial Systems: Lessons from the Vienna Initiative." Globalization and Development no. 2 (2).

Powell, W.W. 1990. "Neither market nor hierarchy: Network form of organization." Research in Organizational Behavior no. 12:295-336.

Powell, Walter W. 2010. "Organizational and Institutional Genesis and Change: The Emergence and Transformation of the Commercial Life Sciences." In The Emergence of Organizations and Markets, edited by John F. Padgett and W.W. Powell, []. Princeton: Princeton University Press.

Roe, Mark. 2011. "The Derivatives Market's Payment Priorities as Financial Crisis Accelerator." Stanford Law Review no. 63 (3):539-590. 
Rosenau, James N. 2002. "Governance in a New Global Order." In Governing Globalization: Power, Authority, and Global Governance, edited by David Held and Anthony McGrew, 70-86. Cambridge: Polity Press.

Sabel, Charles. 1995. "Learning by Monitoring: The Institutions of Economic Development." In Handbook of Economic Sociology, edited by Neil J. Smelser and Richard Svedberg, 137-165. Princeton: Princeton University Press.

Sabel, Charles F., and William H. Simon. 2012. "Contextualizing Regimes: Institutionalization as a Response to the Limits of Interpretation and Policy Engineering." Michigan Law Review no. 112 (7):1266-1307.

Sabel, Charles, and Jonathan Zeitlin. 2008. "Learning from Difference: The New Architecture of Experimentalist Governance in the European Union." European Law Journal no. 14 (3):271-327.

Scharpf, Fritz W. 1999. Governing in Europe: Effective and Democratic? Oxford: Oxford University Press.

Schepel, Harm. 2005. The Constitution of Private Governance: Product Standards in the Regulation of Integrating Markets. Oxford: Hart Publishing.

Schmitter, Philipp C., and Terry Lynn Karl. 1991. "What Deomcracy Is .... and Is Not." Journal of Democracy no. Summer 1991 (2/3):75-88.

Sen, Amartya. 1992. Inequality Reexamined. Cambridge, MA: Harvard University Press.

Sen, Amartya K. 1999. Development as Freedom. 1st ed. New York: Random House.

Simmons, Beth A. 2001. "The International Politics of Harmonization: The Case of Capital Market Regulation." International Organization no. 55 (3):589620.

Slaughter, Anne-Marie. 2004. The New World Order. Princeton, NJ: Princeton University Press.

Smith, Adam. 1976. The Wealth of Nations. Chicago: University of Chicago Press.

Stigler, George. 1971. "The Theory of Economic Regulation." Bell Journal of Economics no. 2 (1):3-21.

Sturm, Susan. 2006. "The Architecture of Inclusion: Advancing Workplace Equity in Higher Education." Harvard Journal of Law and Gender no. 247-334.

Vandenbergh, Michael Pl. 2007. "The New Wal-Mart Effect: The Role of Private Contracting in Global Governance." UCLA Law Review no. 54 (4):913970.

Vander Stichele, Myriam. 2008. Financial Regulation in the European Union: Mapping EU Decision Making Structures on Financial Regulation and Supervision.

Watt, Horatia Muir. 2010. "'Party Autonomy" in international contracts: from the makings of a myth to teh requirements of global governance." European Review of Contract Law:1-34.

Worldbank. 2008. Doing Business: An Independent Evaluation. World Bank. 